\title{
On the Meaning of the First Amendment: Absolutes in the Balance
}

\author{
Wallace Mendelson*
}

Doctrines are the most frightful tyrants to which men ever are subject, because doctrines get inside of a man's reason and betray him against himself.

-W. G. Sumner ${ }^{1}$

TN A RECENT article, Mr. Laurent Frantz criticizes the Supreme Court's 1 "balancing of interests" approach in free speech cases. In the course of his argument, he also lampoons the "absolutist" approach of the dissenters, and chides its chief spokesman for putting his argument "largely in the form that the first amendment 'means what it says." "2 Yet in criticizing the Court, Mr. Frantz himself rests largely on what he seems to assume is a clear meaning in the "constitutional text"- and its history. ${ }^{3}$

In support of the Court's balancing position, I suggest that the language of the first amendment is highly ambiguous, and that this ambiguity is at best compounded by history. Professor Chafee put it in a thimble: "The truth is, I think, that the framers had no very clear idea as to what they meant by 'the freedom of speech or of the press." "4 Indeed, perhaps it is not going too far to suggest that there is no more equivocal word in the English language than "freedom." What Lincoln said of "liberty" is relevant here: "The world has never had a good definition of [it]." $\mathrm{He}$ also pointed out that what is freedom for the lion is death for the lamb. In short, however clear the thou-shalt-not part of the amendment may be, its chain of meaning cannot transcend the fogginess of its weakest link. Surely the framers would have communicated more clearly if they had omitted the weasel-word, and provided simply, "Congress shall pass no law abridging (or restricting) speech." This suggests, of course, that they used the word "freedom" as a limiting or qualifying, not an enlarging, term-a reference presumably to the narrow conception of free utterance that prevailed in the late eighteenth century. Finally, it is noteworthy that even so stout a libertarian as Alexander Meiklejohn has chided those who insist that the words "abridging the freedom of speech or of the press" are "plain words, easily understood."

* Professor of Government, University of Texas.

1 HitchNer \& Harbold, MOdern GovernMent 509 (1962).

2 Frantz, The First Amendment in the Balance, 71 YaIE L.J. 1424, 1432 (1962).

3 Id. at $1433-44,1446$.

4 Chafee, Book Review, 62 HaRv. L. REv. 891,898 (1949).

5 Meiklejohn, The First Amendment Is an Absolute, 1961 Sup. Cr. REv. 245, 247. 
Of course, as Mr. Frantz suggests, we are entitled to seek clarification in history. Doing so, he cites Jefferson's statement that "it is time enough for the rightful purposes of civil government for its officers to interfere when principles break out into overt acts against peace and good order." But this is not only selective history, it is selective Jefferson. Referring to the "licentiousness" of the press that opposed him, the first of the Jeffersonians observed:

This is a dangerous state of things, and the press ought to be restored to its credibility if possible. The restraints provided by the laws of the States are sufficient for this, if applied. And I have, therefore, long thought that a few prosecutions of the most prominent offenders would have a wholesome effect. ... Not a general prosecution, for that would look like persecution; but a selected one. ${ }^{7}$

Some of us may be excused for finding in these combined statements as much equivocation as in the undefined terms of the first amendment itself.

Holmes presumably was one of the greatest of legal historians. Yet he gave at different times opposite interpretations of the historic meaning of the amendment. Speaking for himself and Brandeis, he observed that "History seems to me against the notion [that] the First Amendment left the common law of seditious libel in force." $\mathrm{A}$ few years earlier he had written for the Court: "[T]he main purpose of such constitutional provisions is 'to prevent all such previous restraints . . . as had been practiced by other governments,' and they do not prevent the subsequent punishment of such as may be deemed contrary to the public welfare." In this statement Holmes had the support of Cooley, who maintained that its Blackstonian outlook "has been followed by American commentators of standard authority as embodying correctly the idea incorporated in the constitutional law of the country by the provisions in the American Bill of Rights." 10 To support this proposition Cooley justifiably cites Kent, Story, and Rawle.

While Holmes' switch suggests that the historic purpose of the first amendment is something less than obvious, Mr. Frantz may find comfort in the fact that the Justice's later position was the more liberal one. Professor Chafee also seems to support the charge of vagueness, but by a switch from a generous to a more restricted view. Thus he first asserted that the framers intended "to wipe out the common law of sedition, and

6 Frantz, supra note 2, at 1446.

7 Letter from Thomas Jefferson to Thomas McKean, Feb. 19, 1803, in 8 The Writrincs of Thomas Jefrerson 216, 218-19 (Ford ed. 1897). For extensive evidence of the restricted conception of free utterance of Jefferson, and indeed of many of the Founding Fathers, see Levy, Liberty and the First Anendment: 1790-1800, 78 AM. Hist. Rev. 22 (1962).

8 Abrains v. United States, 250 U.S. 616, 630 (1919).

9 Patterson v. Colorado, 215 U.S. 454, 462 (1907).

10 Cooley, Constitutional Limitations 420 (3d ed. 1874). 
make further prosecutions for criticism of the government, without any incitement to law-breaking, forever impossible."11

It would be ironical if Holmes reversed himself under the influence of Chafee, ${ }^{12}$ because Chafee later appears to have altered his own position:

[The] argument that all the freedoms within the First Amendment are not open to any governmental restrictions ... leans far too heavily on the absolute nature of its language. ... Especially significant is the contemporaneous evidence that the phrase "freedom of the press" was viewed against a background of familiar legal institutions which men of 1791 did not regard as objectionable, such as damage suits for libel. Many state constitutions of this time included guarantees of freedom of speech and press which have been treated as having approximately the same scope as the federal provisions. Some of these, as in Massachusetts, were absolute in terms, while others . . expressly imposed responsibility for abuse of the right. The precise nature of the state constitutional language did not matter; the early interpretation was much the same. Not only were private libel suits allowed, but also punishments for criminal libel and for contempt of court. For instance, there were several Massachusetts convictions around 1800 for attacking the conduct of the legislature and public officials. ... .

The truth is, I think, that the framers had no very clear idea as to what they meant by "the freedom of speech or of the press," but we can say ... with reasonable assurance.... [that] the freedom which Congress was forbidden to abridge was not, for them, some absolute concept which had never existed on earth. ${ }^{13}$

Henry Schofield's "Freedom of the Press in the United States," which appeared in 1914, seems to be the seedbed of the modern libertarian conception of the first amendment. It begins, however, with the admission that the "nearly if not quite unanimous expressed view of our judges always has been, and is, that the constitutional declarations of liberty of the press are only declaratory of the English common-law right protected by the English courts at the time of the Revolution. . ."14 Of course, it may be that Professor Schofield, writing 123 years after adoption of the amendment, had a truer insight into that history than judges and commentators who witnessed or participated in it, but surely there is room for respectful doubt.

So far, I have meant only to suggest that at best (from the liberal point of view) history is a somewhat less than obvious key to the meaning of the first amendment. Surely, however, no such discussion can fail to men-

11 Chafee, Freedom of Speech in Wartime, 32 HaRv. L. REv. 932, 947 (1919).

12 Chafee's initial position appeared in the June issue of the Harvard Law Review in 1919. Holmes' switch found expression in the Abrams case which was argued in October, and decided in November, 1919.

13 Chafee, Book Review, 62 Harv. L. Rev. 891, 897-98 (1949). (Emphasis added.)

14 Schofield, Freedom of the Press in the United States, in 2 Essays on Constirutionad LAW AND EQUITY 510, 511 (1921). 
tion Leonard Levy's powerful (if reluctant) case that history speaks clearly in these matters-but in a way that contradicts the libertarian position. ${ }^{15}$

For those who are not moved by his "textual and historical" arguments, Mr. Frantz offers three "fundamental policy reasons" for a more active judicial role in expression, than in economic, cases:

An economic mistake or injustice [by Congress] does not interfere with the political process and that process therefore remains open for its correction or redress if the courts refuse relief. The same cannot be said where legislation results in infringement of political rights, for the injured can hardly rely for redress on the very weapons of which they are deprived. ${ }^{16}$

This is difficult to follow. By the Interstate Commerce Act, Congress deprives a railroad owner of his "freedom" to charge what the traffic will bear. By the Smith Act, Congress deprives a Communist of his "freedom" to teach and advocate violent overthrow of government. Yet both the railroad owner and the Communist are perfectly free to seek political redress, i.e., repeal of the measure deemed offensive. Both may speak freely in favor of a change in the law. Any substantial legislative interference with that kind of freedom would certainly have hard going in the Supreme Court.17 Even the leader of the antiactivists has made his position clear on that point. ${ }^{18}$

Mr. Frantz's second policy reason for giving free utterance a "preferred place" is that

economic interests are typically represented in legislative bodies-or are able to obtain a hearing from them. Despised ideological minorities typically are not. In extreme situations such as those which give rise to first amendment test cases, their political influence may be less than zero, for it may be better politics for a legislator to abuse them than to listen to their grievances. ${ }^{18}$

Surely we cannot pretend that all economic interests have substantial "political influence," nor that all other interests are politically impotent. Mr. Frantz's distinction then is not between the economic and the noneconomic, but between claims which have much political leverage and those which have little or none. On this basis, some economic interests ought to enjoy a "preferred place" (including perhaps a presumption of unconstitutionality for offending legislation), just as some spiritual interests should have only a second-class status. This might entail some difficul-

15 Levy, Legacy of Suppression (1960).

16 Frantz, supra note 2, at 1446.

17 See De Jonge v. Oregon, 299 U.S. 353, 365-66 (1937).

18 West Virginia Bd. of Educ. v. Barnette, 319 U.S. 624, 664 (1943); Minersville School Dist. v. Gobitis, 310 U.S. 586, 600 (1940).

${ }^{10}$ Frantz, supra note 2, at 1447. 
ties in application. Would the crucial test refer to absolute or relative political influence? How would such values be measured? How much political strength would be required to justify a "deferred" judicial place? Would a politically negligible religious group enjoy an advantage in the courts that would be denied to the Catholic Church? Would the latter have a "preferred place" vis-à-vis protestantism? Ideally, of course, legislators and all of us would give every "despised minority" a respectful hearing, but surely the first amendment does not require it.

The final policy reason presented on behalf of libertarianism on the Bench is that while "activism" in economic cases restricts the scope of "popular choice," activism in utterance cases expands it. ${ }^{20}$ But surely a judicial veto of anticommunist legislation limits the range of popular government just as effectively as a judicial veto of minimum-wage legislation. Both say to the people these are choices you may not make. And is it absolutely clear that democracy is poisoned by suppressing those who preach violence when all the avenues of peaceful change are open? Men of the Weimar Republic, like those of pre-1948 Czeckoslovakia, might have some interesting thoughts on that question.

Having bludgeoned both the balancing and the absolutist gambits in speech cases, Mr. Frantz concludes by insisting that constitutionally protected freedom of speech ought to be "defined."21 Yet strangely (for one who is so concerned for freedom of popular choice) he thinks this should be done not by a constitutional convention, nor by Congress, but by the Supreme Court. To insist that "freedom of speech" needs defining is to concede what $I$ have been arguing: that it is not adequately defined either in the language of the Constitution, or by history, or by considerations of public pohicy so unquestionable as to be fit subjects for judicial notice.

It is largely because of the absence of defining standards, I suggest, that the Court has resorted openly to balancing in free speech cases. We have had too many opinions that hide the inevitable weighing process by pretending that decisions spring full-blown from the Constitution-a document written generations ago by men who had not the slightest conception of the world in which we live. "It will ever remain a mystery to me," Thomas R. Powell observed, "how intelligent jurists can make these professions of nonparticipation in the judicial process." 22 Open balancmg compels a judge to take full responsibility for his decisions, and promises a particularized, rational account of how he arrives at them-more particularized and more rational at least than the familiar parade of hallowed abstractions, elastic absolutes, and selective history. Moreover, this approach should make it more difficult for judges to rest on their pre- 
dispositions without ever subjecting them to the test of reason. It should also make their accounts more rationally auditable. Above all, the open balancing technique is calculated to leave "the sovereign prerogative of choice" to the people-with the least interference that is compatible with our tradition of judicial review. Absent that tradition in utterance cases, the Court might logically accept Learned Hand's view that the first amendment (like the republican-form-of-government clause ${ }^{23}$ ) is too uncommunicative-too lacking in guidelines-to be treated as law. ${ }^{24}$

Those who find these thoughts offensive may recall that even modern libertarians are far from agreement on the meaning of free speech. Thus its two leading academic advocates-Chafee and Meiklejohn-are deeply divided on matters of scope and limitation. ${ }^{25}$ Similarly, Justices Black and Douglas have found themselves on opposite sides of utterance issues. ${ }^{20}$ Indeed the first amendment idea is so obscure that both of them apparently failed to see a free-expression problem in the compulsory flag salute until it was pointed out by Mr. Justice Jackson. ${ }^{27}$ This obscurity is also revealed in Mr. Justice Black's change of heart with respect to the validity of libel laws ${ }^{28}$-and in the disagreements of Holines and Brandeis. ${ }^{20}$ So too, as we have seen, Jefferson could not agree with himself on the meaning of free communication. Finally, even those two vell springs of Anglo-American freedom, Milton's Areopagitica and Mill's On Liberty, are deeply at odds on the thing that they both eulogize. For surely Mill could not accept Milton's principle that only "neighboring differences, or rather indifferences" are entitled to toleration. ${ }^{30}$

This brings us to the anguished question that Mr. Frantz puts at least by implication: What good is the first amendment, if it is not to be given a "preferred place" by "activist" magistrates? Madison long ago gave the answer: It is futile to rely on judges and "parchment barriers"; politics is the only reliable protection for basic substantive interests.

Of course, Madison introduced and fought for the Bill of Rights-and,

23 See Luther v. Borden, 48 U.S. (7 How.) 1 (1849).

24 HaNd, ThE SPIRIT OF LIBERTY 177-78 (1st ed. 1952).

25 See Chafee, Book Review, 62 Harv. L. Rev. 891 (1949).

26 See, e.g., Communist Party v. Subversive Activities Control Bd., 367 U.S. 1 (1961); Barr v. Mateo, 360 U.S. 564 (1959) ; Tenney v. Brandhove, 341 U.S. 367 (1951).

27 Compare their position in Minersville School Dist. v. Gobitis, 310 U.S. 586 (1940), and Jones v. Opelika, 316 U.S. 584 (1942), with West Virginia Bd. of Educ. v. Barnette, 319 U.S. 624, 643 (1943).

28 Compare his position in Chaplinsky v. New Hampshire, 315 U.S. 568, 572 (1942), with Justice Black and First Amendment "Absolutes": A Public Interview, 37 N.Y.U.L. REv. 549, 557 (1962).

29 See Meyer v. Nebraska, 262 U.S. 390 (1923); Gilbert v. Minnesota, 254 U.S. 325, 334 (1920).

304 THE Works OF JoHn Mnton 349-50 (Patterson ed. 1931). 
in so doing, referred to judicial review in support of it, as libertarians emphasize ad infinitum. ${ }^{31}$ What they fail to mention is that this was Madison under pressure. If the "father of the Constitution" had really wanted a bill of rights, why did he not introduce and fight for one in the constitutional convention? Here is his answer:

I have never thought the omission [of a bill of rights from the original Constitution] a material defect, nor been anxious to supply it even by subsequent amendment, for any other reason than that it is anxiously desired by others....

I have not viewed it in an important light . . . because [among other things] experience proves [its] inefficiency on those occasions when its controul is most needed. . . In Virginia I have seen the bill of rights violated in every instance where it has been opposed to a popular current. ... ${ }^{32}$

Before he was pressured into supporting a bill of rights, Madison insisted the only use of a formal declaration was that "the political truths declared in that solemn manner acquire by degrees the character of fundamental maxims of free government, and as they become incorporated with the national sentiment, counteract the impulses of interest and passion." 33 If the government should act improperly, a bill of rights would be "a good ground for an appeal to the sense of the community." 34 How far this is from judicial review! And how close to Learned Hand's thought that the Bill of Rights is not law, but a moral admonition. ${ }^{35}$

Madison was unenthusiastic about the Bill-of-Rights-Judicial-Review approach because he foresaw a far more reliable, and far more sophisticated, shield for civil liberty: the structure and process of politics. ${ }^{36}$ For him the constitutional diffusion of power and the vast expanse of the nation with its multiplicity of regional, economic, religious, and other interests were the true safeguards. Faction would resist faction; ambition would weigh against ambition. The hopes and fears of each subgroup would check and balance those of all the others. Government could act only after political compromise had found the common denominator of a host of mutually suspicious minorities. In the extended, pluralistic republic of the United States this could not be an easy, overnight venture. No program that had survived the give and take necessary to attain support by a concurrent majority of our incredibly varied factional interests could depart

31 See, e.g., Frantz, supra note 2 , at 1448 n.100.

32 Letter from James Madison to Thomas Jefferson, Oct. 17, 1788, in Padover, The Complete Madison 253-55 (1953).

33 Id. at 254.

34 Id. at 255.

35 See note 24 supra. Even after Madison had brought himself to argue in favor of a national bill of rights, he did not link it with judicial review until Jefferson suggested that he do so. On this, and Jefferson's subsequent disillusionment with judicial review, see Mendelson, Jefferson on Judicial Review: Consistency Through Change, 29 U. CHI. L. Rev. 327 (1962).

$36 \mathrm{His}$ thoughts on this, very inadequately summarized below, will be found in THE FedEraLIST Nos. 10, 51 (Madison). 
substantially from the Nation's moral center of gravity. No governmental system could be expected to achieve more; certainly not by idealistic fiats from the Bench that fly in the face of deeply felt community needs. In short, as Madison saw it, majority rule-given a vast empire of diffused sociopolitical power-was the only reliable security against governmental inhumanity. ${ }^{37}$

Of course, some free speech "indiscretions" might survive the sifting of the social and political processes-the Sedition Act of 1798, the Espionage Act of 1917, the Smith Act of 1940 come to mind. But these (assuming they were unjustified) would necessarily reflect such deep and widespread feelings as to defy judicial veto. The upshot is that Congress has killed thousands of bills reflecting every imaginable form of bigotry, intolerance, and demagogery; the Supreme Court has not yet struck down a national measure on the basis of any provision in the first amendment. ${ }^{38}$ As Madison anticipated, the congressional batting average is about .999; the Court's is .000 .

My point is that liberals appreciate the political processes far too little, and expect far more from judicial review than it has ever been able to deliver. Conservatives no longer make this mistake. They know the cost and frailty of a preferred place in court. Accordingly, since 1937, they have concentrated on legislatures, and have carried off all but a few of the prizes.

Meanwhile a select little company of libertarians-with far less social support than conservatives had in the old days-is trying to repeat all of the Old-Guard mistakes: the twisted history, the tortured parchment, the sugar-coated bias called public policy, the preferred place that can hope only to delay defeat. Sooner or later libertarians will have to face it-the real victories are won in legislatures and at the polls..$^{30}$ Man after all is a political, not a legal, animal.

37 Madison recognized that the sociopolitical check and balance system might not be an adequate restraint upon a state because of the relative paucity of interests at play within its boundaries. This may explain why the Supreme Court has been more willing to impose first amendment ideals upon the states than upon the Nation.

$38 \mathrm{Mr}$. Frantz criticizes the Court for not enforcing the first amendment as "absolutely" as it enforces some other Bill-of-Rights provisions. Frantz, supra note 2, at 1436-38. The answer is presumably that these other provisions are directed largely against judges, administrators, and police officers. It is one thing for the Supreme Court to override them; it is quite another to override the National Legislature acting in its lawmaking capacity. See also note 37 supra.

39 Brown v. Board of Educ., 347 U.S. 483 (1954), was costly indeed, if it convinced libertarians that the judicial process is an effective tool of libertarianism. Eight years after the original decision, all the public schools of one of the defendants (Prince Edward County, Virginia) remained closed. Only $.4 \%$ of the Soutl's Negro public school pupils were in classes with whites-and they were concentrated largely in the border states. Alabama, Mississippi, and South Carolina still had no integrated public schools. What Georgia and Louisiana had achieved could not fairly be called even token integration. See generally Is the South Really Integrating Now?, U.S. News \& World Report, Dec. 10, 1962, p. 78. 